\title{
Correction to: The use of intravenous immunoglobulin gamma for the treatment of severe coronavirus disease 2019: a randomized placebo-controlled double- blind clinical trial
}

Naser Gharebaghi', Rahim Nejadrahim ${ }^{1}$, Seyed Jalil Mousavi ${ }^{1}$, Seyyed-Reza Sadat-Ebrahimi ${ }^{*^{*}}$ and Reza Hajizadeh ${ }^{3^{*}}$

Correction to: BMC Infect Dis (2020) 20:786

https://doi.org/10.1186/s12879-020-05507-4

Following publication of the original article [1], the author identified two errors in the Results section of the Abstract and in Table 2.

The sentence currently reads:

"The in-hospital mortality rate was significantly lower in the IVIg group compared to the control group (6 [20.0\%] vs. 14 [48.3\%], respectively; $\mathrm{P}=0.022$ ). ".

The sentence should read:

"The in-hospital mortality rate was significantly lower in the IVIg group compared to the control group (6 [20.0\%] vs. 14 [48.3\%], respectively; $\mathrm{P}=0.025)$. “.

Furthermore, the correct Table 2 is given below.

The original article [1] has been corrected.

\section{Author details}

'Department of Infectious Diseases, Urmia University of Medical Sciences, Urmia, Iran. ${ }^{2}$ Cardiovascular Research Center, Tabriz University of Medical Sciences, Tabriz, Iran. ${ }^{3}$ Department of Cardiology, Urmia University of Medical Sciences, Urmia, Iran.
Published online: 26 November 2020

Reference

1. Gharebaghi N, et al. The use of intravenous immunoglobulin gamma for the treatment of severe coronavirus disease 2019: a randomized placebocontrolled double-blind clinical trial. BMC Infect Dis. 2020;20:786 https:/doi. org/10.1186/s12879-020-05507-4.

The original article can be found online at https://doi.org/10.1186/s12879 020-05507-4.

*Correspondence: Sadatr@tbzmed.ac.ir; hajizadh.reza@gmail.com

${ }^{2}$ Cardiovascular Research Center, Tabriz University of Medical Sciences, Tabriz, Iran

${ }^{3}$ Department of Cardiology, Urmia University of Medical Sciences, Urmia, Iran Full list of author information is available at the end of the article

(c) The Author(s). 2020 Open Access This article is licensed under a Creative Commons Attribution 4.0 International License, which permits use, sharing, adaptation, distribution and reproduction in any medium or format, as long as you give appropriate credit to the original author(s) and the source, provide a link to the Creative Commons licence, and indicate if changes were made. The images or other third party material in this article are included in the article's Creative Commons licence, unless indicated otherwise in a credit line to the material. If material is not included in the article's Creative Commons licence and your intended use is not permitted by statutory regulation or exceeds the permitted use, you will need to obtain permission directly from the copyright holder. To view a copy of this licence, visit http://creativecommons.org/licenses/by/4.0/ The Creative Commons Public Domain Dedication waiver (http://creativecommons.org/publicdomain/zero/1.0/) applies to the data made available in this article, unless otherwise stated in a credit line to the data. 
Table 2 The relationship between study variables and mortality of patients with severe COVID-19

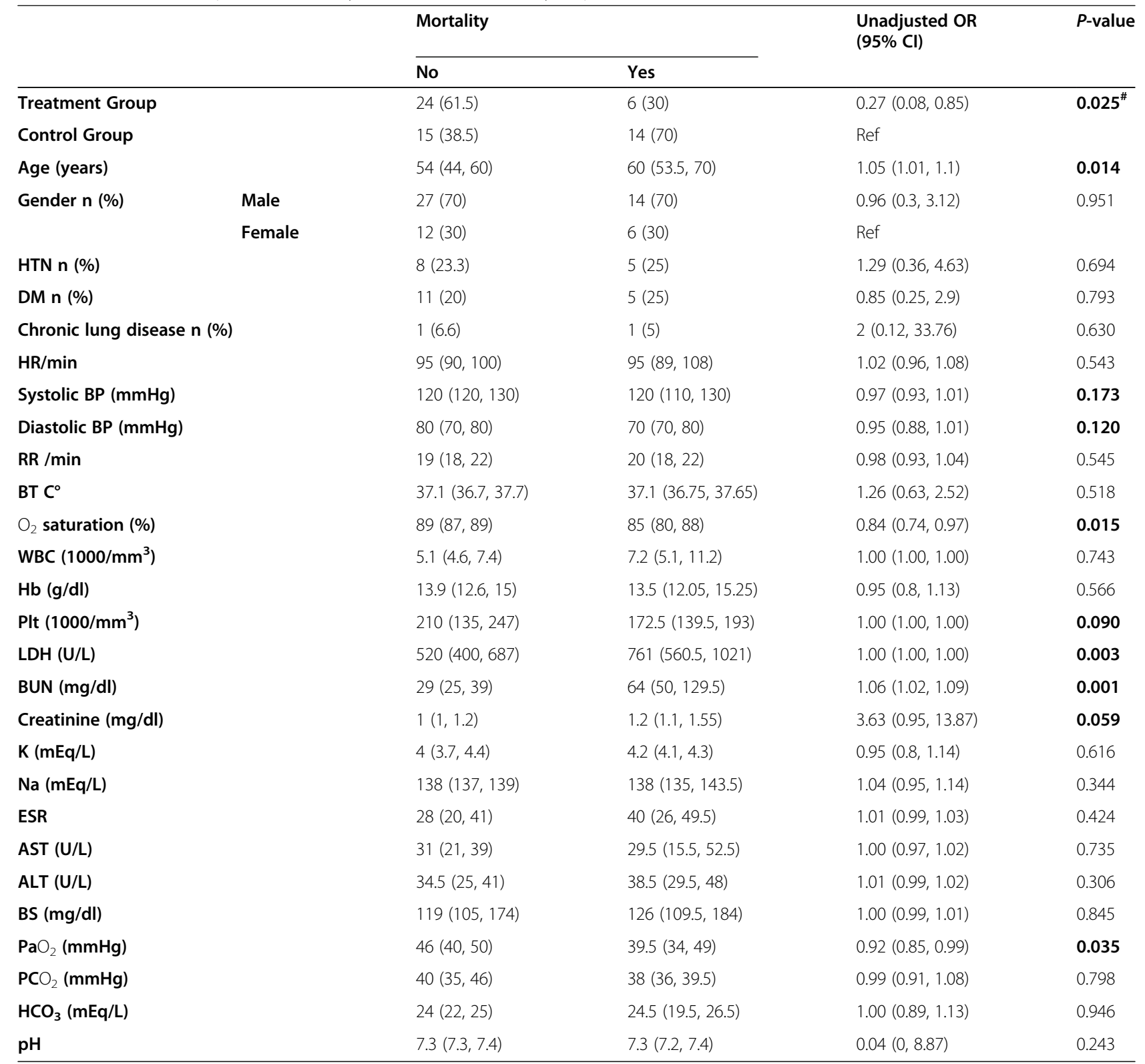

